\title{
CVaR in Measuring Sector's Risk on the Croatian Stock Exchange
}

\author{
Zdravka Aljinović, Andrea Trgo \\ Faculty of Economics, University of Split, Split, Croatia
}

\section{Abstract}

Background: In this paper the well-known risk measurement method Conditional Value-at-Risk ( $C V a R$ ) is applied to the Croatian stock market to estimate the risk for 8 sectors in Croatia. The method and an appropriate backtesting are applied to the sample of 29 stocks grouped into 8 sectors for the three different periods: the period of economic growth 2006-2007, the crisis period 2008-2009 and the post-crisis period 2013-2014, characterized by long-term economic stagnation in Croatia. Objectives: The objective of this paper is to estimate the risk of 8 sectors on the Croatian stock market in three different economic periods and to identify whether the sectors that are risky during the crisis period are the same sectors that are risky in the period of economic growth and economic stagnation. Methods/Approach: The Conditional Valve-at-Risk method and an appropriate backtesting are applied. Results: Empirical findings indicate that sectors that are risky in the period of economic growth are not the same sectors that are risky during the period of economic crisis or stagnation. Conclusions: In all the three periods, the least risky sectors were Hotel-management, Tourism, Food, and Staples Retailing. The Construction sector in all the three periods was among the riskiest sectors.

Keywords: Conditional Valve-at-Risk (CVaR), Croatian stock market, sector's risk JEL classification: G19

Paper type: Case Study

Received: Jan 31, 2018

Accepted: Apr 21, 2018

Citation: Aljinović, Z., Trgo, A. (2018), "CVaR in Measuring Sector's Risk on the Croatian Stock Exchange", Business Systems Research, Vol. 9, No. 2, pp. 8-17.

DOI: 10.2478/bsrj-2018-0015

\section{Introduction}

Increase in trading activities and large portfolios held by financial participants on financial markets have made market risk measurement primary concern for regulators and risk managers. The crisis in the financial markets has also highlighted the key importance of an efficient credit risk management system and the importance that this system has in preserving financial stability. It is imperative that credit risk is measured and understood in extreme conditions.

In this process, it is important to understand which sectors of activity are potentially the most vulnerable in dynamic economic circumstances. Excessive concentration of exposure to potentially vulnerable sectors can significantly contribute to the difficulties faced by lenders in times of economic downturn. Understanding the risk of a particular sector of activity is essential for lenders to 
ensure that there is not too much concentration of credit risk in a particular sector. The risk of particular sectors is also important for investors in the financial markets to ensure optimum asset allocation in the portfolio.

As a reaction to the great financial crisis during the twentieth century, which has resulted in bankruptcy of many financial institutions, the last twenty years in modern finance have developed a number of concepts for risk management and measurement. From the day of appearance within JP Morgan Bank, the risk measure Value-at-Risk (VaR) attracts a huge attention and with time it became one of the most controversial financial instruments, being at the same time very much criticised and very much in use (Hafsa, 2015).

VaR, defined as a statistical measure which assesses the risk of some asset or the whole portfolio expressed with one number - the worst estimated loss for a certain time horizon and a certain confidence level, due to its simplicity, applicability and universality, became very popular and widely used risk measure. Basel Committee for Banking Supervision in Basel II standards put VaR as the key factor in risk management and VaR became industrial standard for market risks measurement "(Basel Committee on Banking Supervision, 2004)".

If the distribution of prices of an asset is given at the certain moment $t$, VaR represents the difference between the invested amount of money and the value, which is not going to be failed in a\% case - the value that corresponds to the 1- a percentile of the distribution. One of the most common critics of the VaR says that with VaR we do not have any information about the values from the tail of the distribution - the values which exceed the value of VaR. Information about unexpected events important for the firm (small probability, high losses) is not included in VaR (Rootzen et al., 1999). The risk measure, which gives information about losses from the tail of distribution, which exceed VaR, is Conditional Value-atRisk (CVaR). Actually, for a given time horizon and confidence level a, CVaR is defined as the conditional expectation of losses greater than VaR.

Maybe the biggest objection on the $\mathrm{VaR}$ is that it is not the coherent risk measure because it does not fulfil the subadditivity condition: $\rho(X+Y) \leq \rho(X)+\rho(Y)$, i.e. VaR of a portfolio is greater than the sum of VaRs of constituents of a portfolio (Artzner et al., 1999), (Dowd, 2002). This can discourage a portfolio diversification and lead to the dangerous risk concentration. It can happen that well diversified portfolio requires more of regulatory capital than the worse diversified one. In the paper (Artzner et al., 1999) the concept of a coherent risk measure is presented and authors had shown that among three conventional risk measures: VaR, variance and CVaR, only CVaR is a coherent risk measure. This good feature of CVaR, along with some other, are presented by several authors (e.g. Uryasev, 2000; Acerbi et al., 2002; Krokhmal et al., 2002; Uryasev et al., 2008).

We can say that CVaR has superior mathematical characteristics over VaR; CVaR keeps good properties of VaR and overcomes its shortages.

The main goal of the paper is to estimate a CVaR of eight sectors on the Croatian stock market to get insight into riskiness of a particular sector during different economic periods. Our intensive literature review presents that no attempt has been found to estimate a sector's risk by using CVaR method in the context of Croatian stock market. As such, this paper is conducted to provide insight into riskiness of a particular sector on the Croatian stock market and changes in sector's riskiness during different economic periods by using CVaR method. The analysis is done for 29 stocks grouped into 8 sectors, for the three different periods, pre-crisis, crisis and postcrisis. Knowing and understanding sectors' risk is very important for all investors and participants on the market, primarily from the aspect of possible adversely risk 
concentration in particular sectors. Identifying sectoral overconcentration is essential to managing portfolio credit risk (Allen et al., 2012). Estimating a risk for various industries has played an important and necessary tool for investors to improve investment efficiency and to achieve optimal outcomes (Tran et al., 2017).

This paper is structured as follows. Following this Introduction, the next section explains the data and methodology used. Results of the study are presented and analysed in the third section, followed by discussion and concluding remarks.

\section{Data and Methodology}

\section{Data}

The first criterion for choosing the stocks sample was liquidity, since calculations are based on daily trading data and for precise and correct results, the active trading is a prerequisite. According to this criterion, 41 stocks included in the Crobex Plus Index on the 14 August 2015 together with 12 stocks with turnover greater than 10 mil HRK on the Zagreb Stock Exchange (ZSE) for 2014, are taken. Further, the necessity of having a good basis of trading data for all of the three observed periods and appearance of a stock splits for two stocks - meaning appearance of extreme values and consequently wrong calculations of sector's risk, lead us to the sample of 30 stocks divided into 9 sectors. Since in the Telecommunication sector only one stock remained, ERNT-R-A, it is decided to proceed without this one-stock sector. Finally, the sample for the analysis is consisting of 29 stocks from 8 sectors given in the Table 1. The sector division follows (Jerončić et al., 2011), due to the rather specific conditions on the Croatian stock market.

Table 1

The stocks sample divided into sectors

\begin{tabular}{cc}
\hline Sector & Stocks \\
\hline Diversified (2) & ADRS-P-A, SNHO-R-A \\
Agriculture (2) & BLJE-R-A, CKML-R-A \\
Financial Services (2) & CROS-R-A, PBZ-R-A \\
Production (4) & KOEI-R-A, ADPL-R-A, DDJH-R-A, PTKM-R-A \\
Construction (4) & DLKV-R-A, IGH-R-A, THNK-R-A, VKDT-R-A \\
Food and Staples Retailing (4) & KRAS-R-A, PODR-R-A, LEDO-R-A, ZVZD-R-A \\
Hotel-Management and Tourism (5) & ARNT-A, LRH-R-A, HUPZ-R-A, MAIS-R-A, TUHO-R-A \\
& ATPL-R-A, LKPC-R-A, JDPL-R-A, LKRI-R-A, ULPL-R-A, \\
Transportation (6) & LPLH-R-A \\
\hline
\end{tabular}

Source: Authors' work

Daily trading prices for chosen stocks are taken for three periods. The first one is the pre-crisis period, 2006-2007, which is characterized with economic growth in Croatia. The second one from 2008 to 2009, is the period of a great financial crisis, where 2008 is characterized with huge fall in all activities on the ZSE followed with significant economic decline in 2009. The third, post-crisis period from 2013 to 2014 is a part of a long-term stagnation period in Croatia. The number of trading dates for observed periods is 499, 502 and 499 , respectively.

\section{Methodology}

For CVaR calculations, the historical method is applied. It is very often used, and probably the simplest non-parametric method. The historical simulation approach has emerged as the most popular method for Value-at-risk calculation in the 
banking Production (Sharma, 2012). Survey of the VaR disclosures of a cross section of 60 US, Canadian and large international banks over 1996-2005 report that 73 percent of banks that disclosed their VaR methodology used historical simulation (Pérignon and al., 2010).

The common characteristic of all non-parametric methods is that they use empirical distributions, while parametric methods assume a certain theoretical distribution. It is assumed that the trend of the latest changes of prices will be continued also in the future. Then the historical data is used for the risk evaluation in the near future. CVaR is calculated as percentiles of the empirical distribution, according to the chosen confidence level. There is no need for approximation of the distribution's parameters like volatility and correlation coefficients; the method is easy for implementation, only the historical rates of return are needed. It allows describing non-normal distributions with fat tails, which are rather often present among financial data (Van den Goorbergh et al., 1999). All this make the historical method very suitable for implementation on the Croatian stock market.

For the CVaR calculations using historical method, we follow the next steps:

- Collection of the stocks' prices classified into sectors for each trading day and each period;

- Calculation of the stocks' daily rates of return;

- Calculation of the sectors' daily rates of return: For example, for the Production sector that means calculation of the rates of return of the portfolio consisting of the four stocks, all with the same proportion of $25 \%$.

- Calculation of potential losses and/or gains for all stocks and appropriate sectors: For example, for the Production sector we assume that we have an investment of 1 million HRK, 250.000 HRK per each stock. By multiplying the rates of return with the appropriate investment, we have results - distribution of gains and losses for each stock and sector.

- Sorting of gains/losses results from the highest to the lowest value and calculation of CVaR; For example, for the Production sector for the 2006-2007 period, from 499 sorted results for the confidence level of $95 \%$, we take $5 \%(499)=24,95$, i.e. 25 worst results, and calculate the value of CVaR as the average of 25 worst results. For the Production sector we got $V a R_{95 \%}=$ $-21.158,12$ and $C V a R_{95 \%}=-30.866,96$.

Evaluation of the CVaR risk approximations is done through so-called backtesting. The Basel Committee defines backtesting as the ex-post comparison of a model's risk approximations with the real daily changes of a portfolio's value through longer periods, or with the hypothetical changes based on the static positions "(Basel Committee on Banking Supervision, 2004)". So, the approximated values of CVaR should be compared with the real losses at the end of an observed period to see if there are cases where the portfolio suffered higher losses than those predicted by the model. Usually, backtesting inquires the frequency of exceeding of the approximated VaR. This failing rate should be in accordance with the applied confidence level. For example, if the daily VaR is approximated with the confidence level of 95\%, the maximum of overruns for the year with 250 trading days is $5 \%(250)=$ 12,5. CVaR backtesting is more complex than the VaR backtesting and there is an opinion that it is one of the reasons why CvaR is not included in the Basel Committee's framework.

For the CVaR backtesting, the loss function $\rho$, which compares the approximated value of CVaR with the real return $r$, in cases where $r$ exceeds VaR, is settled (Letmark, 2010): 


$$
\rho=\left\{\begin{array}{l}
r \text { if } r<\operatorname{VaR} \\
0 \text { if } r \geq \operatorname{VaR}
\end{array}\right.
$$

The function $\rho$ gives to each loss observation from the tail the weight 1 , where the appropriate referent value is simply CVaR.

For example, for the Production sector for the 2006-2007 period, backtesting is done for 80 portfolio's returns from 13 Oct 2007 to 31 Dec 2007. Each portfolio's return is compared with the sector's VaR calculated for the observed period with confidence level of $95 \%$, and in this case that is $-21.158,12$. In the case when return is greater than or equal to the $\mathrm{VaR}$ value, the value 0 is given to the observation; otherwise its value is recorded. From 80 returns 5 of them exceed VaR, and from those five the mean is calculated; the value of the mean is $-29.516,15$. That value is compared with the referent value - CVaR calculated for the observed period with confidence level of $95 \%$ and in this case that is $-30.866,96$. Since $-29.516,15<-$ $30.866,96$ i.e. average of real losses is less than CVaR, it can be concluded that the risk measurement model for the 2006-2007 period is representative, applicable for the Production sector on the Croatian stock market with precise risk evaluation.

\section{Results}

Following the previously described methodology, CVaR calculations together with backtesting conducted for all eight sectors and for all three observed periods. Backtesting results are given in Table 2.

Table 2

CVaR backtesting results

\begin{tabular}{|c|c|c|c|c|c|c|}
\hline \multirow[t]{2}{*}{ Sector / Period } & \multicolumn{2}{|c|}{ 2006-2007 } & \multicolumn{2}{|c|}{$2008-2009$} & \multicolumn{2}{|c|}{$2013-2014$} \\
\hline & $\begin{array}{l}\text { Average } \\
\text { value } \rho\end{array}$ & CVaR 95\% & $\begin{array}{l}\text { Average } \\
\text { value } \rho\end{array}$ & CVaR 95\% & $\begin{array}{l}\text { Average } \\
\text { value } \rho\end{array}$ & CVaR $95 \%$ \\
\hline $\begin{array}{c}\text { Hotel- } \\
\text { Management } \\
\text { and Tourism }\end{array}$ & $-23.248,84$ & $-22.080,46$ & 0,00 & $-47.510,34$ & $-19.786,28$ & $-19.280,08$ \\
\hline $\begin{array}{l}\text { Food and } \\
\text { Staples } \\
\text { Retailing }\end{array}$ & $-22.716,94$ & $-25.058,82$ & $-41.904,94$ & $-55.066,54$ & $-12.530,63$ & $-15.122,48$ \\
\hline $\begin{array}{l}\text { Financial } \\
\text { Services }\end{array}$ & $-26.347,46$ & $-27.429,24$ & 0,00 & $-72.650,05$ & $-21.707,20$ & $-25.170,92$ \\
\hline Construction & $-42.258,14$ & $-32.271,37$ & 0,00 & $-83.276,05$ & 0,00 & $-44.780,10$ \\
\hline Transportation & $-36.927,04$ & $-31.719,01$ & 0,00 & $-84.045,53$ & $-22.834,10$ & $-24.599,64$ \\
\hline Production & $-29.516,15$ & $-30.866,96$ & 0,00 & $-64.010,66$ & $-38.293,14$ & $-36.846,59$ \\
\hline Diversified & $-23.719,19$ & $-31.756,28$ & $-53.285,33$ & $-70.095,85$ & $-21.224,85$ & $-20.475,90$ \\
\hline Agriculture & $-26.623,11$ & $-35.064,61$ & $-51.826,11$ & $-64.532,59$ & $-35.397,25$ & $-24.991,52$ \\
\hline
\end{tabular}

Note: CVaR risk approximations that are lower than the average value $\rho$ are marked in bold Source: Authors' work

We can see that from the total number of $24 \mathrm{CVaR}$ risk approximations on the Croatian stock market for eight sectors through three periods, in 18 cases CVaR is confirmed as representative and applicable. For the crisis period, 2008-2009, CVaR risk approximations were correct for all sectors. 
CVaR is confirmed as absolutely representative and appropriate risk measure for sectors of Food and Staples Retailing and Financial Services, offering precise risk measurement for all observed periods.

The CVaR for all eight sectors on Croatian stock exchange increases in period of great financial crisis 2008-2009 and then decreases in period of stagnation 20132014. For six sectors (Hotel-Management and Tourism, Food and Staples Retailing, Financial Services, Transportation, Diversified and Agriculture) CVaR in period 20132014 is lower than in pre-crisis period 2006-2007 while for 2 sectors (Construction and Production) CVaR is higher in period 2013-2014 than in period 2006-2007.

Figure 1

CVaR Values of Sectors for 3 Observation Periods

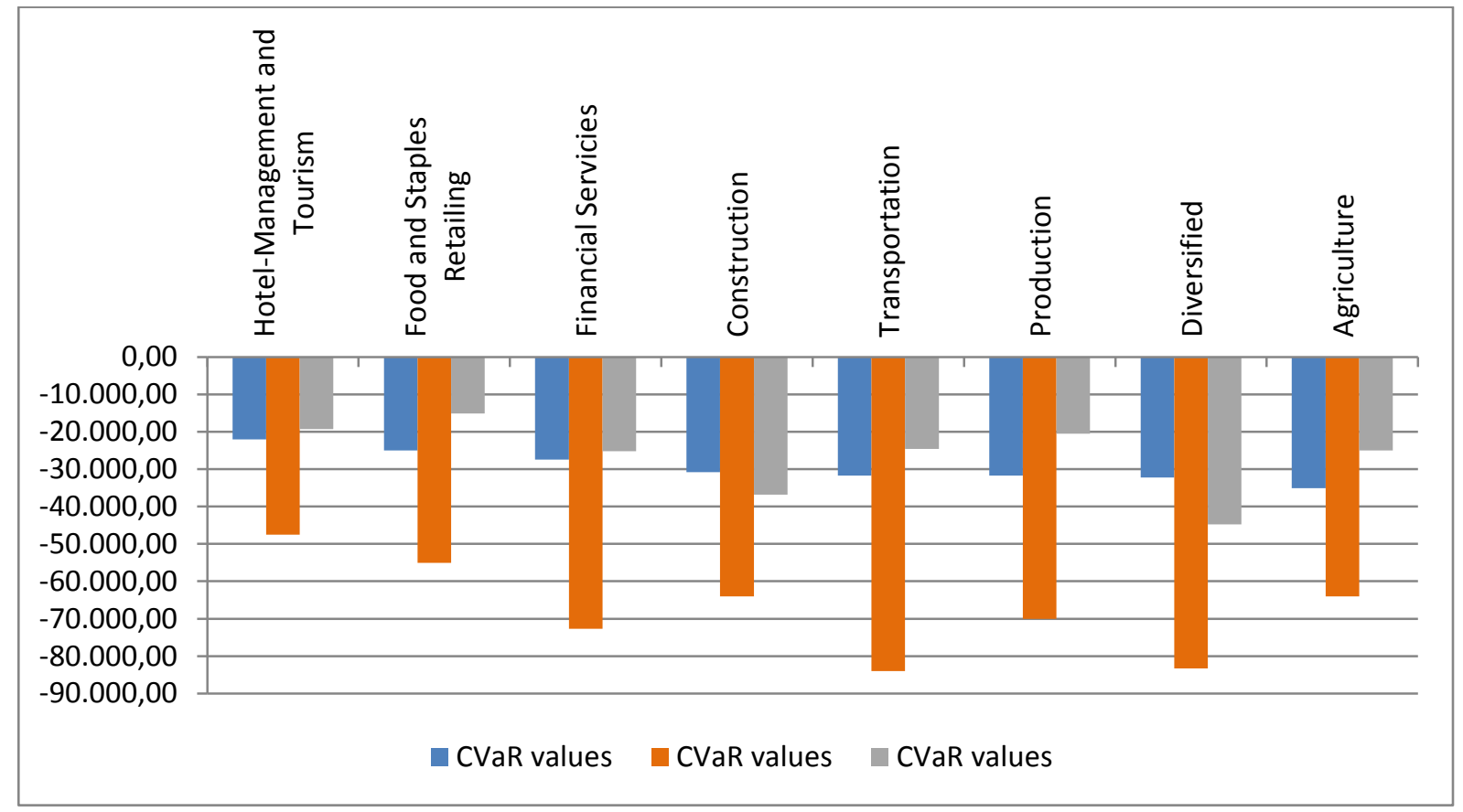

Source: Authors' work

The next step in considering the sector's risk is that the sectors are ranked from the largest to the smallest in such a way that the least risky sector in the context of CVaR is ranked at 1 and the riskiest 8. Except that all sectors show a nominal increase in CVaR, there is a noticeable change in the rank of individual sectors as shown in the Table 3.

During the financial crisis from 2008-2009 all sectors had a CVaR growth, but there was a change in the rankings of individual industries. In the period of crisis, the negative shift in rank had sectors: Transportation, Financial Services and HotelManagement and Tourism, while a positive shift in rank in period 2008-2009 had sectors: Agriculture, Food and Staples Retailing, Production and Diversified. Transportation sector in crisis period 2008-2009 had a negative shift in rank for three places and in that period, was the riskiest sector. Financial Services sector in period of 2008-2009 also had a negative shift in rank for three places and dropped to 6th place of the rank list. The sector that did not have any shift in terms of rank in period 2008-2009 was Construction that remained on 7th place in terms of rank. In the period of financial crisis 2008-2009, the biggest positive movement in terms of rank for four places had sector of Agriculture. 
The biggest changes in ranking were in the middle of the "ranking list", while in all three periods the least risky sectors were Hotel and Tourism and Food and Retail, and the Construction sector was at all periods among the riskiest sectors.

Table 3

Ranking of sectors on the Croatian stock market based on CVaR at 95 per cent level of confidence

\begin{tabular}{|c|c|c|c|c|c|c|}
\hline \multirow[t]{2}{*}{ Sector/Period } & \multicolumn{3}{|c|}{ CVaR rank } & \multicolumn{3}{|c|}{ Change in CVaR rank } \\
\hline & $\begin{array}{l}2006- \\
2007\end{array}$ & $\begin{array}{l}2008- \\
2009\end{array}$ & $\begin{array}{l}2013- \\
2014\end{array}$ & $\begin{array}{c}2008-2009 / \\
2006-2007\end{array}$ & $\begin{array}{l}2013-2014 / \\
2008-2009\end{array}$ & $\begin{array}{l}2013-2014 / \\
2006-2007\end{array}$ \\
\hline $\begin{array}{l}\text { Hotel- } \\
\text { Management } \\
\text { and Tourism }\end{array}$ & 1 & 2 & 2 & -1 & 0 & -1 \\
\hline $\begin{array}{l}\text { Food and Staples } \\
\text { Retailing }\end{array}$ & 2 & 1 & 1 & 1 & 0 & 1 \\
\hline $\begin{array}{l}\text { Financial } \\
\text { Services }\end{array}$ & 3 & 6 & 6 & -3 & 0 & -3 \\
\hline Production & 4 & 3 & 7 & 1 & -4 & -3 \\
\hline Transportation & 5 & 8 & 4 & -3 & 4 & 1 \\
\hline Diversified & 6 & 5 & 3 & 1 & 2 & 3 \\
\hline Construction & 7 & 7 & 8 & 0 & -1 & -1 \\
\hline Agriculture & 8 & 4 & 5 & 4 & -1 & 3 \\
\hline
\end{tabular}

Source: Authors' work

\section{Discussion}

This paper applies CVaR approach in measurement of market risk of eight sectors on Croatian stock exchange for the three periods, pre-crisis period, 2006-2007, which is characterized by economic growth in Croatia, the second period from 2008 to 2009 , is the period of a great financial crisis and the third, post-crisis period from 2013 to 2014 is a part of a long-term stagnation period in Croatia. On the ground of the CVaR approaches, findings indicate that the level of risk across all industries have substantially increased in period of the great financial crisis 2008- 2009 and then in the period 2013-2014 declined. For six sectors risk level in period 2013-2014 was lower than in period 2006-2007, and for two sectors risk level was higher. During all three observed periods, Hotel-Management and Tourism are generally considered the safest (lowest risk) sectors while Construction sector is in all periods among the riskiest. The biggest deterioration in rank during the period of great financial crisis had Transportation sector and Financial Services sector.

The large fall in the rank of the Transportation sector can be explained by the fact that by the end of 2008 there was a significant drop in freight rates (the Baltic Dry (BDI) index, the bulk cargo cost measure on 40 world navigation routes in October 2008, dropped by more than 89 percent compared to May 2008 (Žic, 2008). The decline in freight prices influenced on the reduction in the value of shares related to maritime transport. The deterioration in Financial Services sector rankings is expected, given that banks led the great financial crisis.

The fact that Hotel-Management and Tourism sector in context of CVaR is considered as one of sectors with lowest risk in all three periods is in accordance with the data from Sectoral analysis of Tourism sector of the Zagreb Institute of Economics. The last six years of recession in Croatia has almost left no trace on tourism sector. The reason is that this sector is influenced by other factors. In Croatia, the crucial influence on tourism has three factors: the economic situation on the 
emerging markets, the weather and last but not the least - political stability in the Mediterranean, especially in Greece, as the biggest competitor in the tourist market (Mirošević, 2015).

The share of tourism sector in gross domestic product (GDP) of Croatia in 2015 amounted to 4.7 percent. In comparison, in 2012, the tourism sector accounted for 3.7 percent of Croatian GDP. Increase in the share of the tourism sector in the gross domestic product shows that the tourism sector is a significant driver of development of Croatian economy (Rašić Bakarić, 2017).

As far as the Food and Staples Retail sector is concerned, when the movement of exports and imports of food products from 2008 to 2016 is analysed, it can be argued that in spite of the global economic crisis, the volume of foreign trade in the food Production is increasing, with the increase in exports is higher than increase in imports (Anić, 2017). The above data is in favour of the Food and Staples Retailing sector as one of the least risky sectors in all three periods.

As far as the Construction sector is concerned, it is interesting that the Construction sector is among the riskiest in all three observed periods. The significance and role of Construction sector in the overall economic structure of Croatia in the period from 2001 to 2016 have changed considerably. Three phases are outlined. The first, from 2001 to 2008, when there was a strong growth in activity. The second, from 2009 to 2014, with a recession, and in the third, in the years of 2015 and 2016, stabilization of activity was recorded. Compared to other economic activities in Croatia, construction seems to be the most affected by recession. Since mid-2008 until July 2014, construction activity is continuously decreasing (Buturac, 2017).

\section{Conclusion}

The riskiness of a particular sector varies significantly regarding the period. As it was expected, those sectors which are risky during the crisis are not so risky in pre or post crisis periods. But, there are some "rules" regarding riskiness of sectors on the Croatian stock market: the least risky sectors regardless of the period are HotelManagement and Tourism and Food and Staples Retailing, while the Construction sector is always among riskiest sectors.

A limitation of historical method used to calculate CVaR in this case study is that is based on the assumption that future distributions will have exactly the same format as those from the past and that does not have to be necessary true. Another limitation is that historical method values the same recent data and older data. That can cause bad estimates if there are recent trends, like higher volatility. The choice of number of observations has a significant impact on VaR and CVaR measure, especially when using historical simulation. A large number of observations may include observations that are not relevant to the current situation and may imply a fairly constant VaR measure. A small number of observations makes the calculations sensitive with respect to abnormal outcomes in the recent past and may imply high variance in VaR measures (Letmark, 2010).

Research limitations are closely linked with limitations of historical method used to calculate CVaR and with limitations of Croatian stock market including the small number of stocks listed and even smaller number of actively traded stocks.

Potential for further study includes applying other methods for estimating CVaR on data from this case study in order to compare the results obtained by different methods, as well as more in depth analysis of specific high-risk sectors such as Construction. 


\section{References}

1. Acerbi, C., Tasche, D. (2002), "On the coherence of expected shortfall", Journal of Banking \& Finance, Vol. 26, No. 7, pp. 1487-1503.

2. Allen, D. E., Kramadibrata, A. R., Powell, R. J., Singh, A. K. (2012), "Identifying European Industries with Extreme Default Risk: Application of CVaR Techniques to Transition Matrices", World Review of Business Research, Vol. 2, No. 6, pp. 46-58.

3. Anić, I. D. (2017), "Sektorske analize - Trgovina na malo" (Sectoral Analysis - Retail), Sektorske analize, Vol. 6, No. 52, pp. 1-23.

4. Artzner, P., Delbaen, F., Eber, J. M., Heath, D. (1999), "Coherent Measures of Risk", Mathematical Finance, Vol. 9, No. 3, pp. 203-228.

5. Basel Committee on Banking Supervision (2004), "International Convergence of Capital Measurement and Capital Standards: A Revised Framework", Bank for International Settlements, available at: http://www.bis.org/publ/bcbs107.pdf (30 May 2017).

6. Buturac, G. (2017), "Sektorske analize - Građevinarstvo i nekretnine" (Sectoral Analysis Construction and Real Estate), Sektorske analize, Vol. 6, No. 56, pp. 1-23.

7. Dowd, K. (2002), "Measuring market risk", John Wiley and Sons, Chichester, New York.

8. Hafsa, H. (2015), "CVaR in Portfolio Optimization: An Essay on the French Market", International Journal of Financial Research, Vol. 6, No. 2, pp. 101-111.

9. Jerončić, M., Aljinović, Z. (2011), "Formiranje optimalnog portfelja pomoću Markowitzevog modela uz sektorsku podjelu kompanija" (Creating an optimal portfolio using Markowitz's model with a sectoral division of the companies), Ekonomski pregled, Vol. 62, No. 9-10, pp. 583-606.

10. Krokhmal, P., Palmquist, J., Uryasev, S. (2002), "Portfolio optimization with Conditional Value-at-Risk Objective and Constraints", The Journal of Risk, Vol. 4, No. 2, pp. 11-27.

11. Letmark, M. (2010), "Robustness of Conditional Value-at-Risk (CVaR) when measuring market risk across different asset classes", Master's thesis, Royal Institute of Technology, Stockholm, available at: http://arc.hhs.se/download.aspx?Mediumld=189/ (21 August 2017).

12. Mirošević, H. (2015), "Sektorske analize - Turizam" (Sectoral Analysis - Tourism), Sektorske analize, Vol. 4, No. 41, pp. 1-15.

13. Pérignon, C., Smith D. R. (2010), "The level and quality of Value-at-Risk disclosure by commercial banks", Journal of Banking \& Finance, Vol. 34, No. 2, pp. 362-377.

14. Rašić Bakarić, I. (2017), "Sektorske analize - Turizam" (Sectoral Analysis - Tourism), Sektorske analize, Vol. 6, No. 57, pp. 1-27.

15. Rootzen, H., Kluppelberg, C. (1999), "A single number can't hedge against econoic catastrophes", Ambio, Vol. 28, No.6, pp. 550-555.

16. Sharma M. (2012), "The Historical Simulation Method for Value-at-Risk: A Research Based Evaluation of the Production Favourite", available at: https://papers.ssrn.com/sol3/papers.cfm? abstract_id=2042594 (25 February 2018).

17. Tran, N. P., Vo, D. H., Pham, T. N. (2017), "Measuring market risks for industries in Vietnam: the VaR and CVaR approaches", available at: http://veam.org/wpcontent/uploads/2017/12/46.-Tran-Phu-Ngoc.pdf (7 January 2018).

18. Uryasev, S. (2000), "Conditional Value-at-Risk (CVaR): Optimization Algorithms and Applications", Financial Engineering News, No. 14, pp. 1-5.

19. Uryasev, S., Serriano, G., Sarykalin, S. (2008): "Value-at-Risk vs. Conditional Value-at-Risk in Risk Management and Optimization", Tutorials in Operation Research, INFORMS, available at:

http://www.ise.ufl.edu/uryasev/files/2011/11/VaR_vs_CVaR_INFORMS.pdf (30 May 2017)

20. Van den Goorbergh, R. W. J., Vlaar, P. (1999), "Value-at-Risk Analysis of Stock Returns Historical Simulation, Variance Techniques or Tail Indeks Estimation?", De Nederlandsche Bank Staff Reports, No. 40, available at: https://www.dnb.nl/binaries/sr040 tcm46146818.pdf (30 May 2017).

21. Žic, T. (2008), "Pad indeksa vozarina pridonio urušavanju brodarskih dionica" (The decline in the cargo index contributed to the collapse of shipping shares), Poslovni dnevnik, available at: http://www.poslovni.hr/burze/pad-indeksa-vozarina-pridonio-urusavanjubrodarskih-dionica-96691 (7 January 2018). 


\section{About the authors}

Zdravka Aljinović, Ph.D. is a Full professor at the Faculty of Economics, University of Split, Department of Quantitative Methods. She received her Ph.D. in 2002 on Faculty of Economics, University of Zagreb. Her area of work is teaching and researching mathematics in economics, business and finance. The author can be contacted at zdravka.aljinovic@efst.hr.

Andrea Trgo, univ.spec.oec. is a Head of Finance at Croatian Register of Shipping. She graduated in 2004 on Faculty of Economics, University of Split where she also finished post-graduate specialist study of Business Economics in 2015. Her area of work includes business and finance. The author can be contacted at andreatrgo@gmail.com. 